\title{
RANCANGAN SISTEM SUPLAI DAYA DARURAT PADA PLTG TANJUNG UNCANG 2X35 MW
}

\author{
Ali Mashar, Siti Saodah, Achmad Maulana Fathi \\ Program Studi Teknologi Pembangkit Tenaga Listrik \\ Jurusan Teknik Konversi Energi - Politeknik Negeri Bandung \\ Jl. Gegerkalong Hilir, Ds. Ciwaruga - Bandung 4551 \\ Email :ss_herlina@yahoo.com / siti.saodah@polban.ac.id
}

\begin{abstract}
Abstrak
Pada sebuah pembangkit listrik terdapat peralatan-peralatan vital tambahan (auxiliary load) yang tidak dapat terputus suplai dayanya baik dalam keadaan normal maupun dalam keadaan darurat (suplai daya dari generator utama terputus). Sistem suplai daya darurat merupakan system yang bertugas mensuplai daya pada beban vital tambahan ketika keadaan darurat (emergency). Komponen utama dari sistem suplai daya darurat adalah Emergency Diesel Generator (EDG) berfungsi sebagai pensuplai daya pada sistem tersebut. Besarnya rating daya dari EDG ditentukan dari jumlah beban vital tambahan yang akan disuplai. Berdasarakan pertimbangan kebutuhan daya bebanya, spesifikasi EDG yang digunakan pada PLTG Tanjung Uncang $2 \times 35 \mathrm{MW}$ adalah $1225 \mathrm{kVA}$ dengan tegangan nominal 6,6 kV, frekuensi $50 \mathrm{~Hz}$ dan PF 0,8. Electric Transient and Analysis Program (ETAP) digunakan untuk menverifikasi data beban vital tambahan dan untuk melakukan simulasi load flow dan short circuit pada sistem. Simulasi load flow analysis dilakukan untuk mengetahui aliran daya yang mengalir pada jaringan, sedangkan short circuit analysis dilakukan untuk melihat arus gangguan yang mengalir ketika terjadi short circuit (hubung singkat). Dari simulasi load flow analysis didapatkan bahwa daya yang megalir dari generator memuju jaringan sebesar $754 \mathrm{~kW}$. Dari simulasi short circuit analysis didapatkan jika Bus LV1 terjadi gangguan 3phase fault $1.631 \mathrm{kA}$, jika sumber kegagalan terjadi pada Bus LV2 L-G $1.222 \mathrm{kA}$. Sedangkan jika sumber kegagalan terjadi pada Bus MVI L-L 0.313 kA, jika sumber gangguan terjadi pada Bus MV2 L-L-G 0.260 kA dan jika sumber kegagalan terjadi pada Bus DC sebesar $5.342 \mathrm{kA}$.
\end{abstract}

Kata kunci : EDG, Sistem Suplai Daya Daruat, Load Flow, Short Circuit, ETAP.

\section{PENDAHULUAN}

Pada dasarnya, sistem kelistrikan yang baik adalah sistem kelistrikan yang terjamin keberlangsungannya dengan tidak mengenal waktu. Jika sistem utama terjadi kerusakan atau gangguan yang dapat memutus keberlangsungan berjalannya sistem kelistrikan, maka disinilah diperlukannya backup system agar sistem kelistrikan dapat terjaga keberlangsungannya. $\mathrm{Hal}$ ini dikarenakan perlatan listrik merupakan perlatan yang rentan terkena kerusakan jika dimatikan dengan tidak mengikuti prosedur yang diberikan oleh perusahaan pemproduksinya. Sehingga kelancaran suplai daya adalah kunci pertama dari keandalan sistem kelistrikan secara umum. Oleh karena itu untuk mendapatkan suplai daya secara berkelanjutan haruslah memperhitungkan setiap kejadian yang akan terjadi baik ketika normal meupun ketika darurat (emergency).
Dalam backup system kelistrikan pada pembangkit listrik terdapat beberapa komponen yaitu Uninteruptable Power System (UPS), Startup Diesel Generator, dan Emergency Diesel Generator (EDG). EDG merupakan generator set (genset) yang berfungsi sebagai pensuplai daya untuk beban-beban vital tambahan (auxiliaryload) pada pembangkit ketika dalam keadaan darurat. Keadaan darurat yang dimaksud adalah keadaan ketika suplai daya dari generator utama (main generator) mengalami gangguan atau generator utama bekerja pada kondisi tidak normal.

Beban-beban vital tambahan (auxiliary load) merupakan beban-beban tambahan yang tidak dapat terputus suplai dayanya, baik ketika keadaan normal maupun keadaan darurat. Hal ini dikarenakan beban-beban tambahan tersebut berperan sangat penting dalam pengoperasian sebuah pembangkit listrik. Sebagai contoh beban vital tambahan adalah auxiliary lube oil pump 
motor yang berfungsi sebagai pompa pendistribusian minyak pelumas untuk bearing pada generator utama yang memerlukan tekanan tertentu dan untuk menjaga tekanan tersebut pompa minyak tidak boleh mati. Oleh karenanya catu daya listrik pompa harus tetap hidup. Di sini dibutuhkan EDG untuk menjaga pompa tetap beroperasi. Banyak peralatan lain sejenis yang harus dijaga keberlangsungan kerjanya walaupun tidak ada sumber dari generator utama.

Berdasarkan permasalahan diatas maka dilakukan kajian terkait perancangan sistem suplai daya darurat pada PLTG Tanjung Uncang dengan kapasitas 2x35 MW.

\section{METODOLOGI}

Perancangan suplai daya darurat pada PLTG dimulai dengan indentifikasi terhadap beban-beban vital dan spesifikasi tekniknya, yang nantinya akan disuplai oleh EDG. Selajutnya dilakukan perhitungan jumlah beban vital yang akan disuplai oleh EDG, yang nantinya akan dijadikan landasan untuk menentukan spesifikasi dari EDG.

Perancangan diagram satu garis dari sistem suplai daya darurat didasarkan pada tegangan nominal beban vital yang ada pada PLTG Tanjung Uncang. Analisis dilakukan dengan menggunakan aplikasi software Electrical Transient Analysis Program (ETAP). Sistem kelistrikan dari pembangkit merupakan koneksi antara generator, grid dan komponen tambahan dalam pembangkit listrik yang membutuhkan daya listrik unutk berfungsi. Sistem kelistrikan pada PLTG secara umum ditunjukkan pada Gambar 1.

\section{a. Backup System Kelistrikan Pembangkit}

Sistem kelistrikan yang baik adalah sistem kelistrikan yang terjamin kelangsungannya dengan tidak mengenal waktu. Pada saat sistem utama terjadi kerusakan atau gangguan yang sekitarnya dapat memutus keberlangsungan berjalannya sistem kelistrik, maka disitu mutlak diperlukannya backup system, agar sistem kelistrikan dapat terjaga keberlangsungannya.

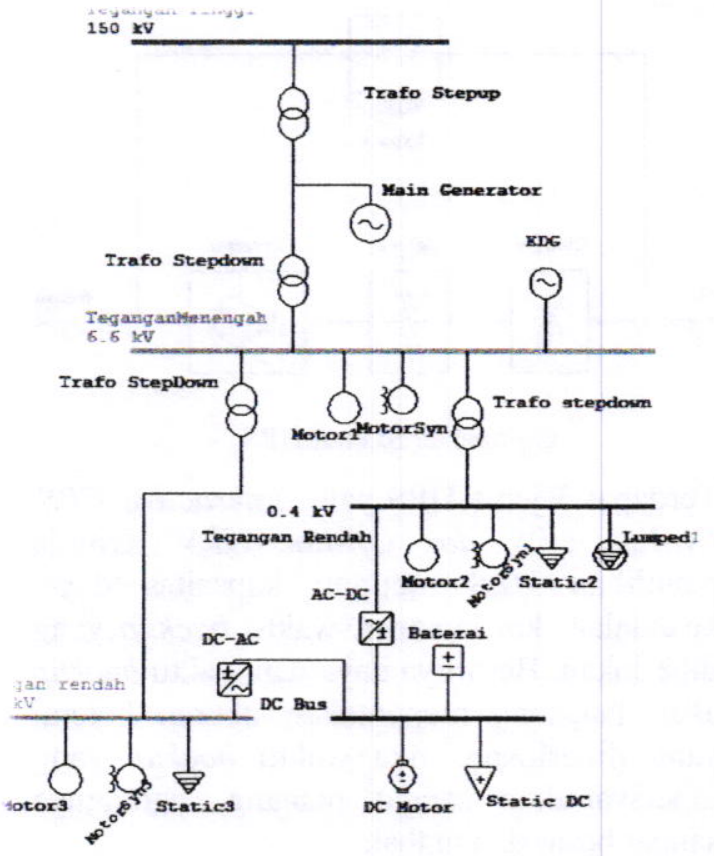

Gambar 1. Diagram Satu Garis Sistem Kelistrikan PLTG

Dengan backup system, walaupun secara kuantitas sistem kelistrikan tidak tersuplai secara keseluruhan namun pada pembangkit ada beberapa peralatan-peralatan yang harus selalu tersuplai oleh tegangan setiap saaat, sehingga keberlangsungan suplai daya pada peralatanperalatan yang menjadi prioritas tidak terganggu. Dalam backup system terdapat tiga komponen yaitu Uninteruptable Power System (UPS), Startup Diesel Generator, Emergency Diesel Generator (EDG) yang bekerja sesuai dengan fungsinya [1]. Untuk lebih mengenal komponen dari sistem backup kelistrikan pada pembangkit, berikut merupakan penjelasan dari komponen-komponen yang dimaksud.

\section{Uninteruptable Power System (UPS)}

Sesuai dengan namanya UPS merupakan sistem daya kebal terhadap gangguan, kebal yang dimaksud adalah suplai daya yang tidak terganggu walau supai daya dari sumber utama mengalami gangguan. Secara umum, skema UPS dapat dilihat pada Gambar 2. 


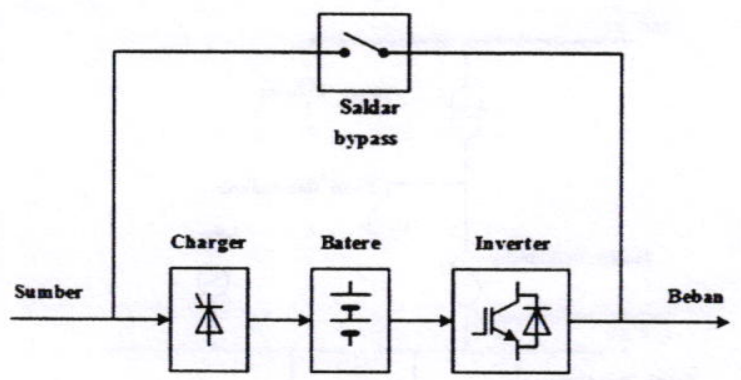

Gambar 2. Skema UPS

Terdapat 3 jenis UPS yaitu Interactive UPS, On-line UPS, dan Off-line UPS. Kriteria pemilihan UPS meliputi kapasitas daya, keandalan dan lamanya waktu backup yang diperlukan. Besarnya daya dan waktu backup akan langsung menentukan ukuran baterai yang diperlukan. Jika waktu backup yang dipersyaratkan sangat panjang, baterainya sangat besar dan mahal.

\section{Startup Diesel Generator}

Dalam sebuah sistem backup kelistrikan pembangkit, terdapat diesel generator yang berfungsi sebagai sumber daya jika generator utama mengalami gangguan. Startup diesel generator merupkan salah satunya, seperti namannya startup disel generator mempunyai fungsi untuk mensuplai daya pada saat starting pembangkit. Besarnya rating daya dari startuo generator tergantung dari beban awal yang akan disuplai. Bebanbeban yang akan disuplai oleh startup disel generator merupakan komponen utama dari pembangkit yang memiliki peranan sangat penting pada saat pengoperasian awal embangkit.

\section{Emergency Diesel Generator (EDG)}

Sesuai dengan namanya EDG merupakan generator set yang dioperasikan pada saat keadaan darurat (emergency). Keadaan darurat dimana suplai daya dari generator utama mengalami gangguan. Berbeda dengan startup diesel generator, EDG mempunyai fungsi sebagai pensuplai daya kepada beban vital tambahan (auxiliary load) yang biasanya bekapasitas daya kecil sampai menengah. Sehingga Edg dapat didefinisikan sebagai peralatan pembangkit yang bertujuan unutk segera dapat membantu suplai daya pada beban vital tambahan.

\section{b. Sistem Suplai Daya Darurat}

Sistem tenaga darurat merupakan sistem daya cadangan yang berfungsi mensuplai daya pada beban vital tambahan, ketika sumber daya utama hilang atau mati. Daya utama dapat hilang karena gangguan jaringan, gangguan pada generator utama, atauoun kesalahan fungsi pada distribusi daya. Dalam sistem suplai daya darurat emergency disel generator (EDG) berfungis sebagai suplai daya dan terdapat beberapa komponen seperti sistem jaringan, sistem proteksi dan sistem pembebanan. Sistem suplai daya darurat, ditunjukkan oleh Gambar 3.

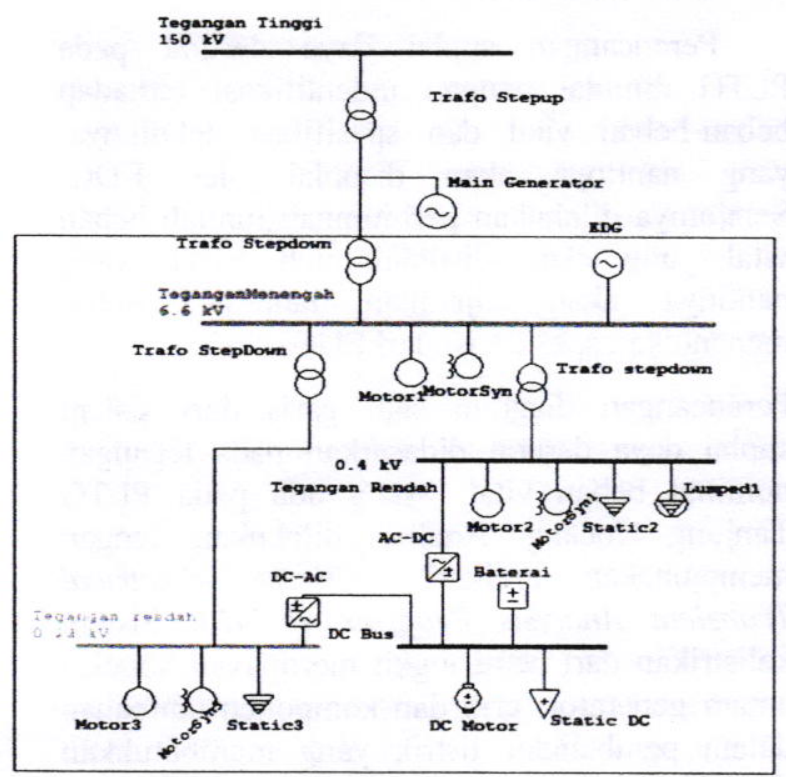

Gambar 3. Diagram Satu Garis Sistem Suplai Daya Darurat

Sistem suplai daya darurat terbagi menjadi empat bagian yaitu : sistem emergency diesel generator (EDG), sistem jaringan, sistem proteksi dan sistem beban.

\section{Sistem Emergency Diesel Generator (EDG)}

EDG merupakan sebuah generator set yang berfungsi untuk mensuplai beban vital tambahan (auxiliary load) ketika keadaan darurat, keadaan darurat yang dimaksud adalah ketika generator utama tidak berfungsi atau sedang mengalami gangguan. Beban vital tambahan merupakan beban plihan yang 
jika terputus dayanya dapat menyebabkan kerusakan pada sistem utama pembangkit.

2. Sistem Jaringan

Distribusi daya diklasifikasikan menjadi lima model jaringan yaitu jaringan radial, jaringan hantaran penghubung, jaringan lingkaran (loop), jaringan spindel, dan sistem gugus atau kluster.

\section{Sistem Proteksi}

Sistem proteksi merupakan sistem pengaman pada peralatan listrik untuk melindungi alat listrik dari gangguan dan bekerja pada kondisi abnormal. Keandalan dan kemampuan suatu sistem tenaga listrik dalam mensuplai daya sangat bergantung pada sistem proteksi yang digunakan. Sistem proteksi terdiri dari pemutus tenaga (circuit breaker), relai proteksi (protection relay), transformator arus, transformator tegangan dan datu daya.

\section{Sistem Beban}

Sistem pembebanan terdapat tiga sifat beban yaitu resistif, kapasitif, dan induktif.

a. Beban Resistif

Beban resistif merupakan suatu resistor murni dan hanya menyerap daya aktif.

$R=\frac{V}{I} \ldots \ldots \ldots \ldots 1$

b. Beban Induktif

Konstruksi beban induktif terdiri dari kumparan kawat yang dililitkan pada sebuah inti, biasanya inti besi. Faktor daya beban induktif antara 0-1 lagging.

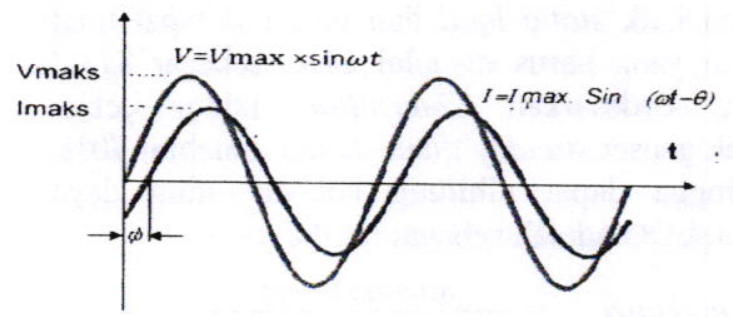

Gambar 4. Arus, Tegangan dan GGL Pada Beban Induktif
Beban induktif menyerap daya aktif dan daya reaktif dengan fasa tegangan mendahului arus sebesar $\varphi$.

c. Beban Kapasitif

Beban kapasitif mengandung suatu rangkaian kapasitor dengan faktor daya antara 0-1 leading. Beban kapasitif menyerap daya aktif dan mengeluarkan daya reaktif.

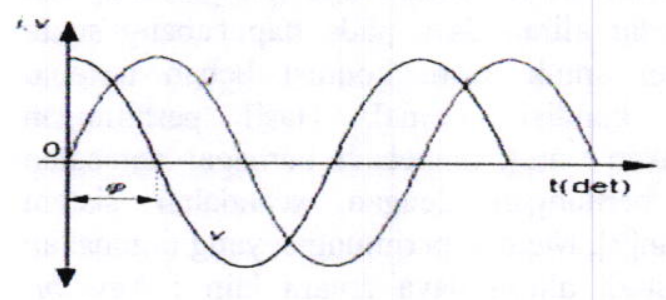

Gambar 5. Arus dan Tegangan GGL Pada Beban Kapasitif

Pada ETAP 12.0.6, terdapat 3 jenis beban yaitu static load, motor dan lumped load.

1) Static Load

Static Load atau beban statis merupakan beban yang tidak memiliki kumparan dan tidak berputar. Daya static load satu phase :

$P=V . I \ldots \ldots \ldots \ldots . .2$

Untuk 3 phase

$P=\sqrt{3} \cdot V . I \ldots \ldots . .3$

2) Motor

Motor listrik digunakan untuk mengkonversi energi listrik menjadi energi mekanik. Daya input motor satu phase :

$P=V . I \cdot \cos \varphi \ldots \ldots .4$

Daya input tiga phase seimbang

$P=\sqrt{3} \cdot$ V.I. $\cos \varphi \ldots \ldots .5$

3) Lumped Load

Lumped Load merupakan beban gabungan dari beban statis dan motor, dengan kata lain lumped load dapat diartikan sebagai beban yang diasumsikan dapat menjadikan beban statis dan dapat menjadi beban motor. 


\section{c. Analisa Daya}

Dalam merancang sebuah sistem jaringan listrik, dilakukan Load flow analysis dan short circuit analysis untuk mengetahui keandalan dari jaringan.

\section{Load Flow Analysis}

Studi aliran daya (load flow) digunakan untuk mengetahui besar vecktor tegangan pada tiap bus dan besar aliran daya pada tiap cabang suatu jaringan untuk suatu kondisi beban tertentu dalam kondisi normal, Hasil perhitungan digunakan untuk menelaah berbagai persoalan yang berhungan dengan keandalan sistem jaringan[2]. Metode perhitungan yang digunakan pada studi aliran daya antara lain : NewtonRaphson, Adaptive Newton Rapshon, Fast Decoupled dan Acclerated Gauss Seidel.

a. Newton Raphson Method

Metode Newton Raphson merumuskan dan diselesaikan itertatif persamaan aliran daya sebagau berikut:

$$
\left[\begin{array}{l}
\Delta P \\
\Delta Q
\end{array}\right]\left[\begin{array}{ll}
J_{1} & J_{2} \\
J_{3} & J_{4}
\end{array}\right]=\left[\begin{array}{l}
\Delta \delta \\
\Delta V
\end{array}\right] \ldots \ldots \ldots 6
$$

b. Adaptive Newton Rapshon

Metode Adaptive Newton Raphson merumuskan dan diselesaikan iteratif persamaan aliran daya sebagai berikut:

$$
f\left(X_{k}+\alpha_{k} \times \Delta x_{k}\right)<f\left(x_{k}\right) \ldots . .7
$$

c. Fast Decoupled

Metode Fast Decoupled merumuskan dan diselesaikan itertatif persamaan aliran daya sebagai berikut:

$$
\begin{aligned}
& {[\Delta P]=\left[J_{1}\right][\Delta \delta] \ldots \ldots .8} \\
& {[\Delta Q]=\left[J_{2}\right][\Delta V] \ldots \ldots \ldots .9}
\end{aligned}
$$

\section{d. Acclerated Gauss}

Metode Acclerated Gauss Seidel merumuskan dan diselerakan iteratif persamaan aliran daya sebagai berikut:

$$
[P+j Q]=\left[V^{T}\right]\left[Y_{\text {bus }}\right][V] \ldots \ldots 10
$$

\section{Short Circuit Analysis}

Hubungan singkat atau short circuit terjadi karena dua titik potensial terhubung secara langsung atau beban 0 (nol) sehingga terjadi aliran arus yang tidak normal dan sangat besar yang biasa. Arus yang ditimbulkan jauh lebih besar dari arus pengenal (arus nominal) peralatan dan terjadi penurunan tegangan pada sistem tenaga listrik. Bila gangguan tidak segera dihilangkan dapat merusak peralatan dalam sistem. Besarnya arus hubung singkat dinyatakan dengan persamaan :

$i=\frac{V_{\text {maks }}}{|Z|}\left[\sin (\omega t+\alpha)-\epsilon^{-\frac{R t}{L}} \sin (\alpha-\theta)\right] \ldots 11$

Jenis short circuit dibagi menjadi empat yaitu 3 phase fault, line to ground fault $(L-G)$, line to line fault $(L-L)$, dan line to line to ground fault $(L-L-G)$.

\section{PERANCANGAN SISTEM SUPLAI DARURAT}

\section{Static Load}

Berlandaskan data beban pada PLTG Tanjung Uncang yang tidak dapat terputus suplai dayanya dan yang termasuk static load ditunjukkan pada Tabel 1. Dari perhitungan beban static load didapatkan total daya adalah $42.865 \mathrm{kVA}$ yang dibulatkan menjadi $42.9 \mathrm{kVA}$.

\section{Motor}

Berdasarkan data beban pada PLTG Tanjung Uncang yang tidak dapat terputus suplai dayanya, berikut klasifikasi bebanyang termasuk motor ditunjukkan pada Tabel 2. Dari perhitungan didapat total daya pada motor adalah $770.341 \mathrm{kVA}$ yang dibulatkan menjadi 770.3 kVA. Sehingga didapatkan total daya beban vital pada PLTG Tanjung Uncang adalah 813.2 kVA.

\section{Pemilihan Jenis Genset}

Untuk menentukan spesifikasi EDG harus memperhitungkan jumlah beban yang akan disuplai [3][4]. Dari perhitungan total daya beban baik static load dan motor didapat total beban yang harus disuplai EDG sebesar 813.2 kVA. Brdesarkan Caterpillar, faktor beban untuk genset standby tidak moleh melebihi $70 \%$. Sehingga dapat dihitung bahwa rating daya untuk EDG adalah sebagai berikut:

$$
\begin{aligned}
\text { Rating Daya } & =\frac{\text { jumlah beban }}{\text { faktor beban maksimum }} \\
& =\frac{813,2 \mathrm{kVA}}{70 \%} \\
& =1161,72 \mathrm{kVA}
\end{aligned}
$$


Tabel 1. Klasifikasi Beban Static

\begin{tabular}{|c|c|c|}
\hline NO & Name & Volt \\
\hline 1 & Anti-conedensation heater for motor $88 \mathrm{BT}-1$ & $230 \mathrm{VAC}$ \\
\hline 2 & Anti-condensation heater for motor $88 \mathrm{BT}-2$ & $230 \mathrm{VAC}$ \\
\hline 3 & Auxiliarie compertment heater & $400 \mathrm{VAC}$ \\
\hline 4 & Load compartment heater & $400 \mathrm{VAC}$ \\
\hline 5 & Turbine compartment heater & $400 \mathrm{VAC}$ \\
\hline 6 & Gas mass flow transmitter & $230 \mathrm{VAC}$ \\
\hline 7 & Gas compartment heater & $400 \mathrm{VAC}$ \\
\hline 8 & Anti-condesation heater for motor $88 \mathrm{QV}-1 \mathrm{~A}$ & $230 \mathrm{VAC}$ \\
\hline 9 & Heat tracing for $\mathrm{G} 064$ & $230 \mathrm{VAC}$ \\
\hline 10 & Motor valve off-line compressor water wash & $230 \mathrm{VAC}$ \\
\hline 11 & Motor valve on-line compressor water wash & $230 \mathrm{VAC}$ \\
\hline 12 & Anti-condensation heater for motor $88 \mathrm{CR}$ & $230 \mathrm{VAC}$ \\
\hline 13 & Anti-condensation heater for motor $88 \mathrm{HQ}-1$ & $230 \mathrm{VAC}$ \\
\hline 14 & Anti-condesation heater for motor $88 \mathrm{QA}$ & $230 \mathrm{VAC}$ \\
\hline 15 & Anti-condensation heater for motor $88 \mathrm{TK}-1$ & $230 \mathrm{VAC}$ \\
\hline 16 & Anti-condensation heater for motor $88 \mathrm{TK}-2$ & $230 \mathrm{VAC}$ \\
\hline 17 & Anti-condensation heater for motor $88 \mathrm{TK}-3$ & $230 \mathrm{VAC}$ \\
\hline 18 & Ignition transformer for $95 \mathrm{SP}-1$ & $230 \mathrm{VAC}$ \\
\hline 19 & Ignition transformer for $95 \mathrm{SP}-10$ & $230 \mathrm{VAC}$ \\
\hline 20 & GT unit accoustical package normal lighting & $230 \mathrm{VAC}$ \\
\hline 21 & GT unit accoustical package sockets & $230 \mathrm{VAC}$ \\
\hline 22 & GT unit accostical package emergency lighting & $125 \mathrm{VDC}$ \\
\hline 23 & GT air flow control (95BT-1 to 95BT-3) & $125 \mathrm{VDC}$ \\
\hline 24 & Load compartment lighting & $125 \mathrm{VDC}$ \\
\hline 25 & Gas module accoustical package emergency lighting & $125 \mathrm{VDC}$ \\
\hline 26 & Gas modul air flow control (95VL- to 95VL-3) & $125 \mathrm{VDC}$ \\
\hline 27 & Total air filter & $230 \mathrm{VAC}$ \\
\hline 28 & Total air filter & $400 \mathrm{VAC}$ \\
\hline 29 & Total air filter & $230 \mathrm{VAC}$ \\
\hline
\end{tabular}

Tabel 2. Klasifikasi Beban Motor

\begin{tabular}{|c|l|c|}
\hline $\mathrm{NO}$ & \multicolumn{1}{|c|}{ Name } & Volt \\
\hline 1 & Cooling air fan motor-acoustisal enclosure GT compartment & $400 \mathrm{VAC}$ \\
\hline 2 & Cooling air fan motor-acoustic enclosure GT compartment & $400 \mathrm{VAC}$ \\
\hline 3 & Cooling air fan motor-acoustic exhaust plenum compartment & $400 \mathrm{VAC}$ \\
\hline 4 & Cooling air fan motor-acoustic enclosure exhaust plenum compartment & $400 \mathrm{VAC}$ \\
\hline 5 & Cooling air fan motor acoustic enclosure load compartment & $400 \mathrm{VAC}$ \\
\hline 6 & Cooling air fan acoustic enclosure load compartment & $400 \mathrm{VAC}$ \\
\hline 7 & Cooling air fan motor gas module acoustic enclosure & $400 \mathrm{VAC}$ \\
\hline 8 & Cooling air fan gas module acoustic enclosure & $400 \mathrm{VAC}$ \\
\hline 9 & Lube oil mist eliminator motor & $400 \mathrm{VAC}$ \\
\hline 10 & Cranking motor & $6.6 \mathrm{kV}$ \\
\hline 11 & Auxiliary hy draulic supply pump motor & $400 \mathrm{VAC}$ \\
\hline 12 & Hydraulic rachet pump motor & $125 \mathrm{VDC}$ \\
\hline 13 & Auxiliary lube oil pump motor & $400 \mathrm{VAC}$ \\
\hline 14 & Emergency lobe oil pump motor & 125 VDC \\
\hline 15 & Turbine exhaust frame cooling blower \& motor & $400 \mathrm{VAC}$ \\
\hline 16 & Turbine exhaust frame cooling blower \& motor & $400 \mathrm{VAC}$ \\
\hline 17 & Turbine exhaust frame cooling blower \& motor & $400 \mathrm{VAC}$ \\
\hline
\end{tabular}

Dengan faktor daya sebesar 0.8 maka berikut spesifikasi dari Edg yang akan digunakan:

$\begin{array}{ll}\text { Rating Daya } & : 1161,72 \mathrm{kVA} \\ \text { Faktor Daya } & : 0,8 \\ \text { Tegangan Nominal } & : 6,6 \mathrm{kV} \\ \text { Frekuensi } & : 50 \mathrm{~Hz}\end{array}$

Berdasarkan genset yang ada dipasaran maka spesifikasi yang paling mendekati adalah Mitsubishi MGS 100HV ytpe 56S-P618 dengan spesifikasi sebegai berikut [5] :

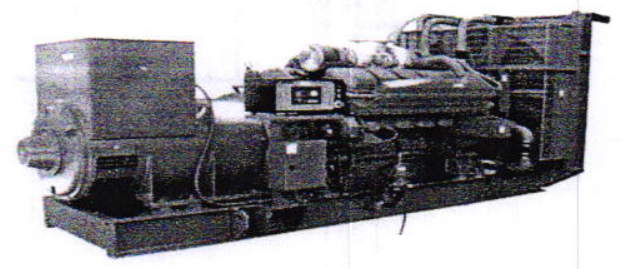

Gambar 6. Mitsubishi MGS 1000HV type 56S-P18

Generator Spesification

Name : Mitsubishi MGS 100HV type 56S-P18

Power : $12225 \mathrm{kVA}$

Voltage : $6,6 \mathrm{kV}$

Frequency: $50 \mathrm{~Hz}$

$P F \quad: 0.8$

\section{Rancangan Diagram Satu Garis Sistem Suplai Daya Darurat}

Dari data beban yang peroleh, gambar 7, untuk PLTG Tanjung Uncang terdapat beberapa beban-beban yang memiliki tegangan yang berbeda, sehingga dapat dibagi menjadi beberapa bus yaitu HV Bus (150kV), Bus MV1 (11,5 kV), Bus MV2 (6,6 kV) Bus LV1 (0,4 kV), Bus LV2 $(0,23 \mathrm{kV})$, dan DC Bus $(0,13 \mathrm{kV})$.

\section{Analisis Rancangan}

\section{Load Flow Analysis}

Dari hasil simulasi load flow didapatkan bahwa Bus LV1 $(0.4 \mathrm{kV})$ Dari hasil simulasi load flow analysis dapat dilihat bahwa Bus LV1 $(0,4 \mathrm{kV})$ menerima aliran daya dari bus MV2 $(6,6 \mathrm{kV})$ sebesar $281 \mathrm{~kW}$, kemudian mengalirkan daya ke beban yang terhubung ke bus LV1 $(0,4 \mathrm{kV})$ yaitu Cmtr1 sebesar $270 \mathrm{~kW}$. 


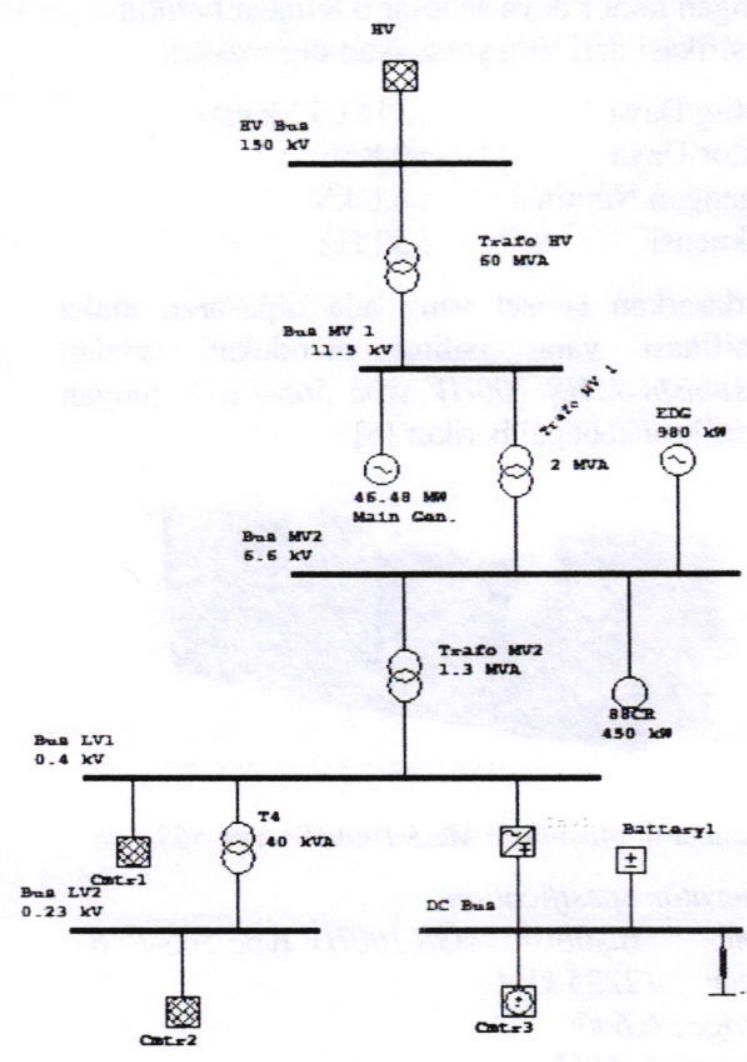

Gambar 7. Diagram Satu Garis Rancangan Sistem

Kelistrikan Sistem Suplai Daya Darurat PLTG Tanjung Uncang

Selain mengalirkan daya ke beban langsung dari bus, LV1 $(0,4 \mathrm{kV})$ juga mengalirkan daya ke bus LV2 $(0,23 \mathrm{kV})$ dengan besar aliran daya sebesar $9 \mathrm{~kW}$. Bus LV2 $(0,23 \mathrm{kV})$ mengalirkan daya sebesar $9 \mathrm{~kW}$ ke beban yaitu Cmtr2, dan menerima aliran daya $9 \mathrm{~kW}$ dari bus LV1 $(0,4$ $\mathrm{kV})$.

Bus MV1 dalam analisis aliran daya ini tidak mengalirkan daya karena diasumsikan main generator dalam keadaam off atau mati ketika EDG bekerja, hal ini dilandaskan karena sistem suplai daya darurat bekerja ketika keadaan darurat atau ketika main generator tidak dapat menyuplai daya pada jaringan.

Bus MV2 terhubung dengan EDG yang menghasilkan daya $754 \mathrm{~kW}$ kemudian daya tersebut mengalir ke Bus MV2 $(6,6 \mathrm{kV})$ sebesar $281 \mathrm{~kW}$ dan ke beban motor $88 \mathrm{CR}$ sebesar 473 $\mathrm{kW}$. Kemudian daya dari bus MV2 $(6,6 \mathrm{kV})$ sebesar $281 \mathrm{~kW}$ mengalir ke bus LV1 $(0,4 \mathrm{kV})$ dan mensuplai beban Cmtrl sebesar $270 \mathrm{~kW}$, dari bus LV1 $(0,4 \mathrm{kV})$ daya mengalir $9 \mathrm{~kW}$ menuju ke LV2 $(0,23 \mathrm{kV})$ untuk mensuplai beban di Cmtr2 yang terhubung pada bus. Untuk lebih jelasnya dapat dilihat pada Tabel 3.

Pada simulasi load flow analysis DC didapatkan bahwa daya yang mengalir dari Batterylmenuju bus $D C(130 \mathrm{~V})$ adalah $14,23 \mathrm{~kW}$, yang selanjutnya mensuplai daya untuk beban Cmtr3yang terhubung pada bus $D C(130 \mathrm{~V})$. Untuk lebih jelasnya mengenai load flow analysis $D C$ berikut report dari simulasi dapat dilihat pada Tabel 4.

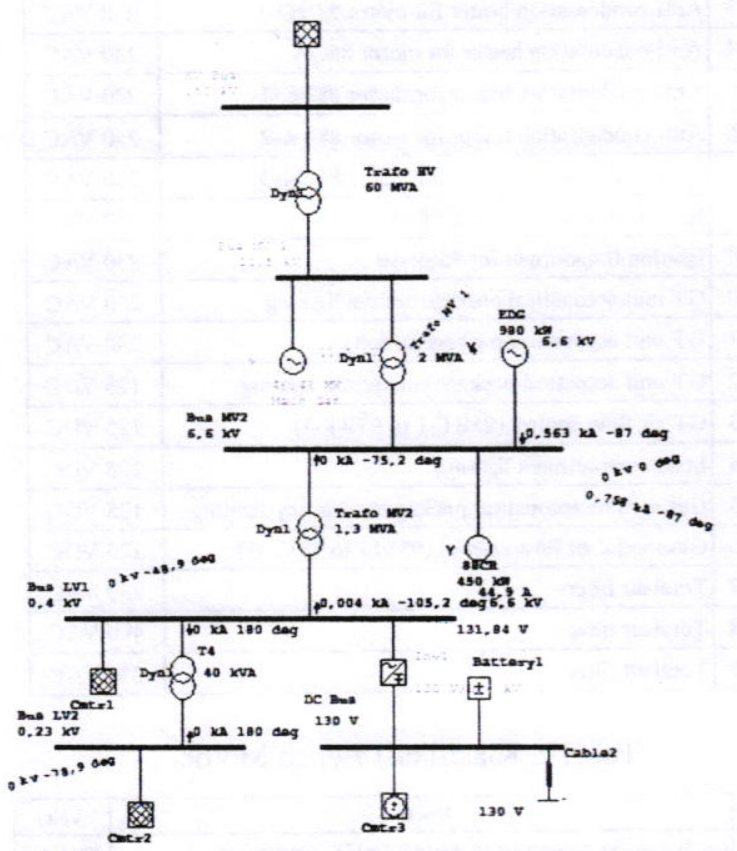

Gambar 8 Diagram Satu Garis Simulasi 3phase fault pada Bus MV2

\section{Short Circuit Analysis}

Untuk merancangan sebuah sistem suplai daya yang andal haruslah memperhitungkan keadaan pada saat sistem sulpai daya mendapat gangguan. Untuk rancangan sistem suplai daya darurat pada PLTG Tanjung Uncang 2x35 MW, sistem diasumsikan terjadi hubung singkat (short circuit). Diagram satu garis simulasi short circuit, seperti tampak pada gambar 8. Hasil analisis short circuit tampak pada Tabel 6 hingga Tabel 8. 
Tabel 3. Report Load Flow Analysis AC

10AD FI,OW REMRI

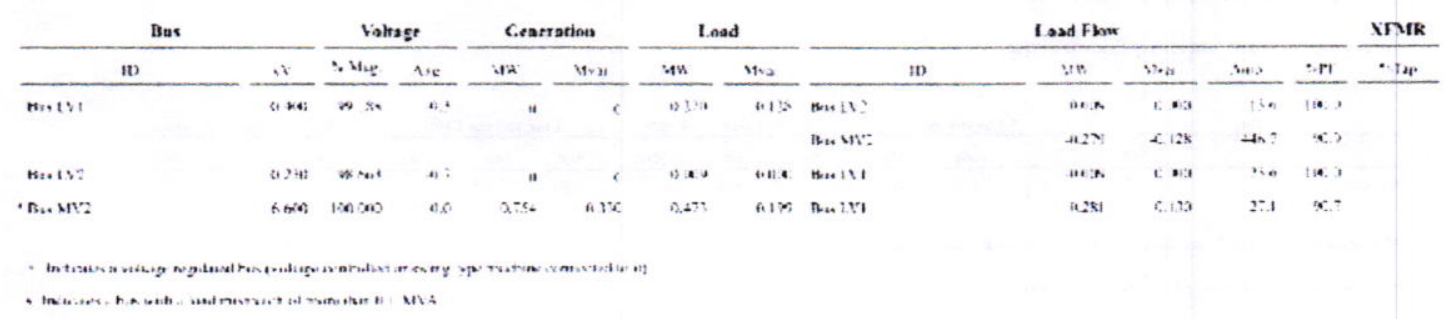

Tabel 4. Report Load Flow Analysis DC

1.OADFIOW RFPORT

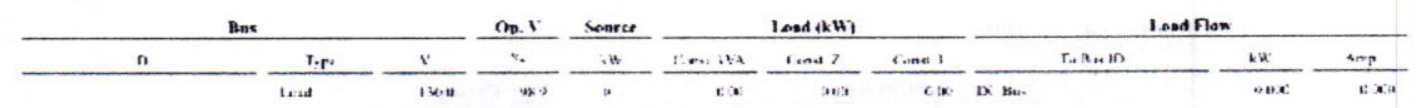

ux Ba:

Leis

1 wo

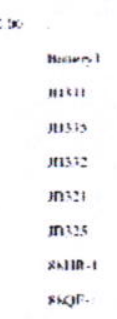

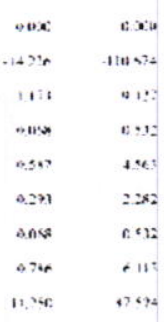

Tabel 5. Report Simulasi short circuit pada Bus MV2

Shat Cercuit Summan Reners

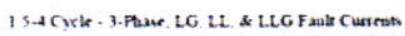

Prefult Viltage $-100 \%$ of the Bas Nomeal Voltage

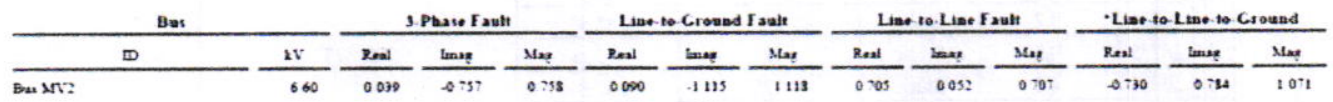

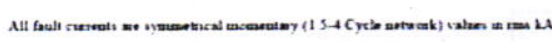

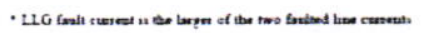

Tabel 6. Report Simulasi Short Circuit pada Bus LV1

Shont-Gircuit Summan Reroent

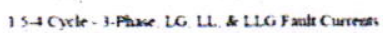

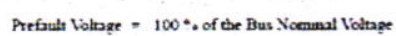

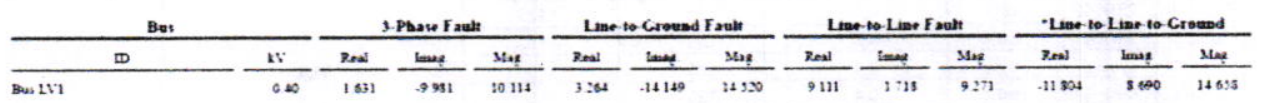

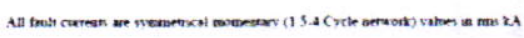

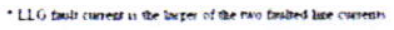


Tabel 7. Report Simulasi Short Circuit pada Bus LV2

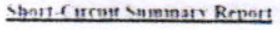

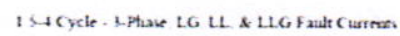

Prefralt Vithape - $100^{\circ}$ of the Bes Nounal Voltage

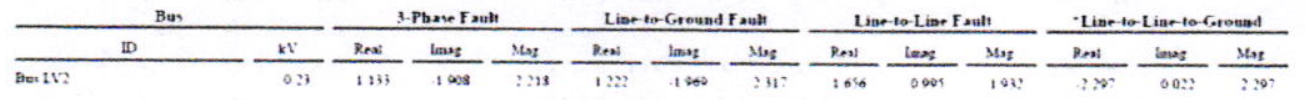

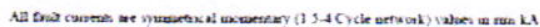

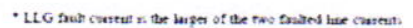

Tabel 8. Report Short Circuit DC shart-rircuit Report

Futhad Bus: DC Bus

Nowual 13060

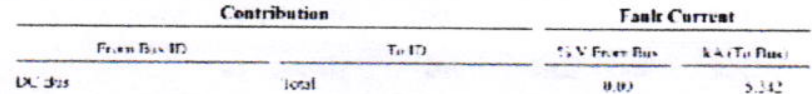

\begin{tabular}{|c|c|c|c|}
\hline bXs & De Dus & a.s & 0.000 \\
\hline : & Ux Uv: & 0.09 & 0.00 \\
\hline weyz & ix Uus & o.p & wine \\
\hline$w 121$ & in thus & 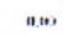 & n.100 \\
\hline P: $2:$ & of fow & $n . b \mathrm{~s}$ & $n+\infty)$ \\
\hline Wir & on Hes & 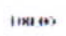 & $n(w)$ \\
\hline kogr. 1 & $n \in n_{m}$ & Ina (t) & A MS \\
\hline rimatil & ne nus & $D \cdots$ & $4+17$ \\
\hline & IKC Dus & 0.03 & $0 . \mathrm{m}$ \\
\hline
\end{tabular}

Tabel 9. Setelan Arus Pada Beban Cmtr3

\begin{tabular}{|c|l|c|c|c|c|c|}
\hline NO & ID & Arus Nominal & Jenis Beban & Faktor Pengali (\%) & Setelan Arus (A) & Setelan Arus Pangkal Cabang (A) \\
\hline 1 & 88 HR-1 & 6 & Motor & 400 & 24 \\
\hline 2 & $88 Q$ QE- 1 & 86,5 & Motor & 400 & 346 \\
\hline 3 & JB331 & 9,2 & Static & 125 & 11,5 \\
\hline 4 & JB335 & 0,5 & Static & 125 & 0,625 \\
\hline 5 & JB332 & 4,6 & Static & 125 & 5,75 \\
\hline 6 & JB321 & 2,3 & Static & 125 & 2,875 \\
\hline 7 & JB325 & 0,5 & Static & 125 & 0,625
\end{tabular}

Tabel 10. Setelan Arus Pada Beban Cmtr2

\begin{tabular}{|c|c|c|c|c|c|c|}
\hline NO & ID & Jenis Beban & Arus Nominal (A) & Faktor Pengali (\%) & Setelan Arus (A) & Arus Setelan Pangkal Cabang (A) \\
\hline 1 & G064 & \begin{tabular}{|l} 
Static \\
\end{tabular} & 1,3 & \begin{tabular}{|l|}
125 \\
\end{tabular} & 1,6 & \multirow{19}{*}{51,1} \\
\hline 2 & $20 T W-1$ & Static & 0,2 & 125 & 0,25 & \\
\hline 3 & $20 \mathrm{TW}-3$ & Static & 0,2 & 125 & 0,25 & \\
\hline 4 & $23 \mathrm{CR}$ & Static & 1,4 & 125 & 1,75 & \\
\hline 5 & $23 \mathrm{HQ}=1$ & Static & 0,1 & 125 & 0,125 & \\
\hline 6 & $230 \mathrm{~A}-1$ & Static & 0,1 & 125 & 0,125 & \\
\hline 7 & 23TK-1 & Static & 0,1 & 125 & 0,125 & \\
\hline 8 & $23 T K-2$ & Static & 0,1 & 125 & 0,125 & \\
\hline 9 & $237 K-3$ & Static & 0,1 & 125 & 0,125 & \\
\hline 10 & 95SG-1 & Static & 0,4 & 125 & 0,5 & \\
\hline 11 & 95SG-10 & Static & 0,4 & 125 & 0,5 & \\
\hline 12 & $238 T-1$ & Static & 0,1 & 125 & 0,125 & \\
\hline 13 & $238 T-2$ & Static & 0,1 & 125 & 0,125 & \\
\hline 14 & $96 \mathrm{VM}-1$ & Static & 0,04 & 125 & 0,05 & \\
\hline 15 & $23 Q V-1 A$ & Static & 0,1 & 125 & 0,125 & \\
\hline 16 & JB331 & Static & 1,5 & 125 & 1,875 & \\
\hline 17 & JB331 & Static & 16 & 125 & 20 & \\
\hline 18 & AF2 & Static & 2,5 & 125 & 3,125 & \\
\hline 19 & AF3 & Static & 0,1 & 125 & 0,125 & \\
\hline
\end{tabular}


Tabel 11. Setelan Arus Pada Beban Cmtr 1

\begin{tabular}{|c|c|c|c|c|c|c|}
\hline NO & ID & Jenis Beban & Arus Nominal (A) & Faktor Pengali (\%) & Setelan Arus (A) & Setelan Arus Pangkal Cabang (A) \\
\hline 1 & $88 \mathrm{HQ}-1$ & \begin{tabular}{|l|} 
Motor \\
\end{tabular} & 28,1 & \begin{tabular}{|l|}
400 \\
\end{tabular} & 112,4 & \multirow{19}{*}{1837,975} \\
\hline 2 & $88 \mathrm{HQA}-1$ & Motor & 51,5 & 400 & 206 & \\
\hline 3 & $88 T K-1$ & Motor & 51,5 & 400 & 206 & \\
\hline 4 & $887 \mathrm{~T}-2$ & Motor & 51,5 & 400 & 206 & \\
\hline 5 & $887 K-3$ & Static & 51,5 & 400 & 206 & \\
\hline 6 & $23 \mathrm{HA}-30$ & Static & 13 & 125 & 16,25 & \\
\hline 7 & $23 \mathrm{HG}-30$ & Static & 14,4 & 125 & 18 & \\
\hline 8 & $23 \mathrm{HT}-30$ & Motor & 14,4 & 400 & 57,6 & \\
\hline 9 & 88BT-1 & Motor & 35,6 & 400 & 142,4 & \\
\hline 10 & $88 \mathrm{BT}-2$ & Motor & 35,6 & 400 & 142,4 & \\
\hline 11 & 88EF-1 & Motor & 15,4 & 400 & 61,6 & \\
\hline 12 & $88 E F-2$ & Motor & 15,4 & 400 & 61,6 & \\
\hline 13 & $88 V G-1$ & Motor & 15,4 & 400 & 61,6 & \\
\hline 14 & $88 V G-2$ & Static & 15,4 & 125 & 19,25 & \\
\hline 15 & 23HA-11 & Motor & 5,6 & 400 & 22,4 & \\
\hline 16 & $88 \mathrm{VL}-1$ & Motor & 4,7 & 400 & 18,8 & \\
\hline 17 & $88 \mathrm{VL}-2$ & Motor & 4,7 & 400 & 18,8 & \\
\hline 18 & $88 Q V-1 A$ & Motor & 13,5 & 400 & 54 & \\
\hline 19 & AF1 & Static & 0,7 & 125 & 0,875 & \\
\hline
\end{tabular}

\section{Sistem Proteksi}

Dalam perancangan sistem suplai daya darurat, ditentukan juga sistem proktesi yang bertujuan untuk melindungi beban vital dari arus lebih jika terjadi kegagalan pada sistem. Seperti yang tertera pada PUIL 2000 ayat 5.5.4.1 "Proteksi beban lebih (arus lebih) dimaksudkan untuk melindungi motor, dan perlengkapan kendali motor, terhadap pemanasan berlebihan sebagai akibat beban lebih atau sebagai akibat motor tak dapat diasut. Beban lebih atau arus lebih waktu motor beoperasi, bila bertahan cukup lama, akan mengakibatkan kerusakaan atau pemanasan yang berbahaya pada motor tersebut." [6].

Pada PUIL 2000 terdapat standar untuk menentukan setelan arus pemutus sirkit jika terjadi hubung pendek atau arus beban lebih. Ayat 5.5.4.1 PUIL 2000 menjelaskan standar penentuan pengaman arus lebih untuk beban beban vital. Berdasarkan aturan tersebut selanjutnya dihitung setelan arus untuk beban pada Cmtr3 sebagai berikut:

Setelan Arus = Arus Nominal $x$ Faktor Pengali

\section{Setelan Arus Pangkal Cabang = Setelan Arus} Tertinggi + Total Setelan Arus

Untuk lebih jelasnya mengenai hasil perhitungan dapat dilihat pada Tabel 9 sampai Tabel 11.

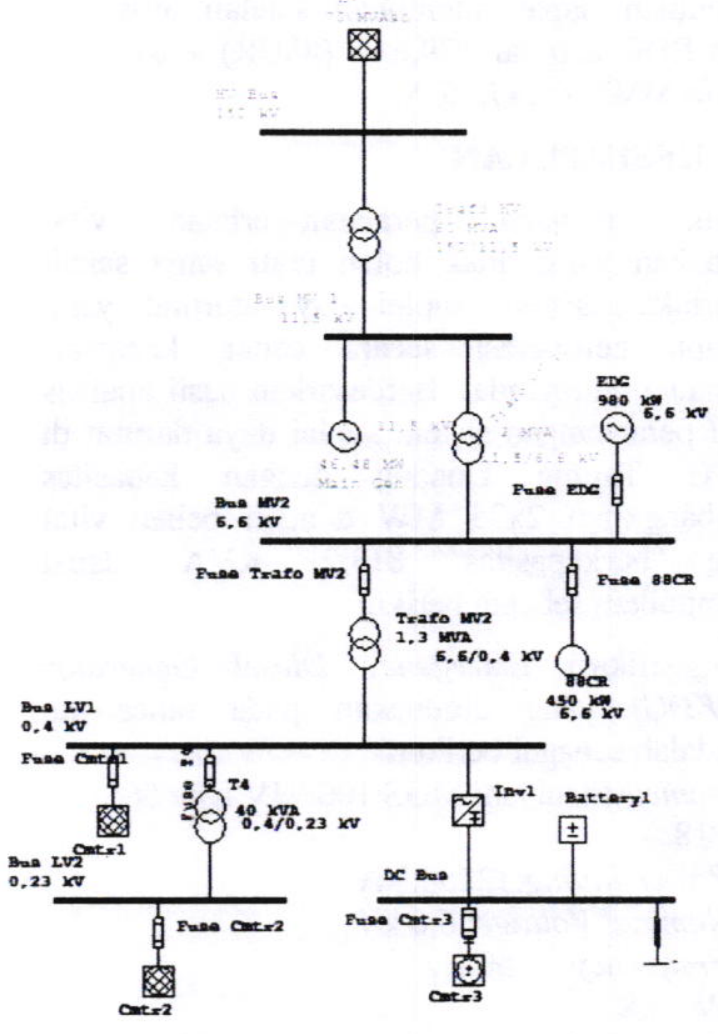

Gambar 1Diagram Satu Garis Rancangan Sistem Suplai Daya Darurat dengan Fuse

Dari simulasi load flow analysis juga diketahui bahwa arus pengenal pada transformator (T4) sebesar 13,6 A dan transformator (Trafo MV2) sebesar 27.1 A. Dilandaskan oleh ayat 5.8.1.8.1 maka setelan arus pada T4 dan Trafo MV2 dapat dihitung dengan rumus sebagai berikut: 
Setelan Arus T4 = Arus Pengenal $\times 250 \%$

$$
\begin{aligned}
& =13,6 \mathrm{~A} \times 250 \% \\
& =34 \mathrm{~A}
\end{aligned}
$$

Setelan Arus T4 = Arus Pengenal $\times 250 \%$

$$
\begin{aligned}
& =27,1 \mathrm{~A} \times 250 \% \\
& =67,75 \mathrm{~A}
\end{aligned}
$$

Untuk lebih jelasnya letak $\mathrm{CB}$ pada $\mathrm{T} 4$ dan Trafo MV2, diagram satu garis dapat dilihat pada Gambar 8.

Seperti yang sudah dijelaskan pada Ayat 5.5.4.1 PUIL 2000, maka setelan arus pada beban motor (88CR) dapat dirumuskan sebagai berikut:

$$
\text { Arus } \begin{aligned}
88 C R & =\text { Arus Pengenal } \times 400 \% \\
& =44,9 \mathrm{~A} \times 400 \% \\
& =179,6 \mathrm{~A}
\end{aligned}
$$

Kemudian dapat ditentukan setelan arus $\mathrm{CB}$ pada EDG sebesar 179,6 A (88CR) + 67,75 A $($ Trafo MV2 $)=247,35$ A.

\section{KESIMPULAN}

Untuk menjaga peralatan-perlatan vital tambahan yang tidak boleh mati sama sekali diperlukan sistem suplai daya darurat yang mampu beroperasi secara cepat, kapasitas memadai dan handal. Berdasarkan hasil analisis hasil perancangan sistem suplai daya darurat di PLTG Tajung Uncang dengan kapasitas pembangkitan $2 \times 35$ MW dengan beban vital yang berkapasitas 813,2 KVA dapat disimpulkan sebagai berikut

1. Spesifikasi Emergency Diesel Generator (EDG) yang digunakan pada rancangan adalah sebagai berikut:

Name:Mitsubishi MGS 1000HV type 56S-

P18

Power Rating:1225 kVA

Nominal Voltage: $6,6 \mathrm{kV}$

Frequency : $50 \mathrm{~Hz}$

$P F: 0,8$

2. Dari simulasi load flow analysis bahwa daya yang dari EDG (Emergency Diesel Generator) menuju beban-beban vital tambahan melalui bus dapat dilihat pada Tabel 12.
Tabel 12Hasil Simulasi Load Flow

\begin{tabular}{|c|c|}
\hline Nama Bus & Jumlah Daya \\
\hline MV 2 & $754 \mathrm{~kW}$ \\
\hline LV1 & $281 \mathrm{~kW}$ \\
\hline LV2 & $9 \mathrm{~kW}$ \\
\hline DC & $14.23 \mathrm{~kW}$ \\
\hline
\end{tabular}

3. Dari simulasi short circuit didapatkan bahwa

\begin{tabular}{|c|c|c|c|c|c|}
\hline \multirow{2}{*}{\multicolumn{2}{|c|}{ Io Namm Bus }} & 3phosefaudt & Line to ground faut ( $(L-G)$ & line to line fauts (L-L) & Fine to line to groind \\
\hline & & $H_{H}$ & $k d$ & $k d$ & fant $(L-L-G)$ kd \\
\hline 1 & IVI & 1.631 & 3.264 & 9.111 & 11.804 \\
\hline 2 & LV2 & 1.133 & 1.222 & 1.656 & .2297 \\
\hline & WV2 & 0.039 & 0.000 & 0.052 & -0.730 \\
\hline
\end{tabular}
arus yang mengalir dari jaringan menuju sumber kegagalan pada Bus DC sebesar $5.342 \mathrm{kA}$, dan hasil simulasi hasil short circuit pada bus lainnya dapat dilihat pada Tabel 13

Tabel 13Hasil Simulasi Short Circuit

\section{Daftar Pustaka}

[1] IEEE, "446 Recommeded Practice For Emergency And Standby Power System For Industrial And Commercial Application", USA: IEEE, 1995.

[2] John J. Grainger and W.D. Stevenson Jr., "Power System Analysis", McGraw Hill International Book Company, 1994

[3] Kartono, A. Mashar dan B. Puguh, "Perancangan Pembangkit Listrik Tenaga Thermal", Bandung: Politeknik Negeri Bandung, 2013.

[4] Setiawan, "Backup Sistem Kelistrikan PLTGU PT. Indonesia Power UBP Semarang Dengan Startup Diesel Generator 6,3 kV dan 400V'.

[5] Mitsubishi Heavy Infudtries, Mitsubishi MGS series $1000 \mathrm{HV}$, Tokyo: Engine Sales Department.

[6] Standar Nasional Indonesia (SNI), Persyaratan Umum Instalasi Listrik 2000 (PUIL 2000), Jakarta: Badan Standarisasi Nasional, 2000. 